\title{
Analysis of videos about malaria on YouTube: Evaluation of the Turkish and English content
}

\section{Sıtma ile ilgili YouTube videolarının analizi: Türkçe ve İngilizce içeriklerin değerlendirilmesi}

\author{
Sümeyye KAZANCIOĞLU1 (ID), Hürrem BODUR² (ID)
}

\section{ABSTRACT}

Objective: Malaria is an important mosquito-borne disease that affects half of the world's population (mainly in tropical and subtropical countries). The contents of internet videos, though popular sources of public health information, are often unverified and questionable.

Methods: In this study, the contents of the most relevantly viewed 150 videos (58 videos in English and 39 videos for Turkish were selected for further analysis) regarding malaria were analyzed on YouTube which is a popular source of health information.

Results: All videos had a total of 14373885 views, with 281199 likes, 4810 dislikes, and 24339 comments. The health information websites $(n=38,39.2 \%)$ were the major source of all videos. According to the source, there was a significant difference between Turkish and English videos $(p<0.001)$. Health information websites are dominant sources for English videos (53.4\%) and news agencies are dominant sources for Turkish videos (48.7\%). 66 videos were classified as useful $(68.0 \%$, English $(n=54)$, Turkish $(n=12))$ and 8 were classified as misleading (8.24\%, English $(n=2)$, Turkish $(n=6))$. The number of views, likes, views/day, and video power

\section{ÖZET}

Amaç: Sitma, dünya nüfusunun yarısını (esas olarak tropik ve subtropikal ülkelerde) etkileyen sivrisinek kaynaklı önemli bir hastalıktır. İnternet videolarının içerikleri, halk sağı̆ğı bilgilerinin popüler kaynakları olmasına rağmen, genellikle doğrulanmamıș ve sorgulanabilir niteliktedir.

Yöntem: Bu çalıșmada, popüler bir sağlık bilgi kaynağı olan YouTube'da sıtma ile ilgili en alakalı izlenen 150 videonun (58 İngilizce video ve 39 Türkçe video daha detaylı analiz için seçildi) içeriği analiz edildi.

Bulgular: Tüm videolar; 281.199 beğeni, 4.810 beğenmeme ve 24.339 yoruma sahip olarak, toplam 14.373.885 kez izlendi. Sağlık bilgisi veren web siteleri ( $n=38, \% 39.2)$ tüm videoların ana kaynağıydı. Kaynağa göre bakıldığında; Türkçe ve İngilizce videolar arasında anlamlı bir fark vardı $(p<0,001)$. Sağlık bilgisi veren web siteleri İngilizce videolar için $(\% 53,4)$, haber ajansları ise Türkçe videolar için $(\% 48,7)$ ana kaynaklardı. 66 video faydalı $(\% 68$, İngilizce $(n=54)$, Türkçe $(n=12))$ ve 8 video yanıltıcı (İngilizce $(n=2)$, Türkçe $(n=6)$ olarak sınıflandırıldı. Yararlı videolarda izlenme, beğeni, izlenme/gün sayısı ve video güç indeksi (VPI) yanıltıcı

'Ankara City Hospital, Department of Infectious Diseases and Clinical Microbiology, Ankara

${ }^{2}$ Health Science University, Ankara City Hospital, Department of Infectious Diseases and Clinical Microbiology, Ankara

İletişim / Corresponding Author : Sümeyye KAZANCIOĞLU

Ankara Şehir Hastanesi Üniversiteler Mahallesi 1604. Cadde No: 9 Çankaya - Ankara - Türkiye Geliş Tarihi / Received : 07.06 .2021

E-posta / E-mail : sumeyye_yildiz@hotmail.com

DOI ID : 10.5505/TurkHijyen.2021.09699

Kazancıoğlu S, Bodur H. Analysis of videos about malaria on YouTube: Evaluation of the Turkish and English content.

Turk Hij Den Biyol Derg, 2021; 78(4): 467 - 476 
index (VPI) in the useful videos were higher than misleading videos. The length was positively correlated with the number of views, dislikes, likes, comments, views/day, and VPI. The DISCERN score of videos was positively correlated with length, the number of views, dislikes, likes, comments, views/day, and VPI.

Conclusion: In today's globalizing world, it is more important to create contents that will provide accurate information about malaria for the people living or traveling in endemic areas on the internet platforms like YouTube.

Key Words: Malaria, Plasmodium, internet, YouTube, mosquito-borne diseases, travel-related infections videolara göre daha yüksek bulundur. Video uzunluğu ile görüntülenme, beğenmeme, beğeni, yorum, görüntüleme/gün ve VPI arasında pozitif yönde korelasyon saptandı. DISCERN skoru ile uzunluk, görüntüleme sayısı, beğenmeme, beğeni, yorum, görüntüleme/gün ve VPI arasında pozitif yönde korelasyon saptandı.

Sonuç: Globalleșen günümüz dünyasında; YouTube gibi internet platformlarında, endemik bölgelerde yașayan veya seyahat eden kișiler için sıtma hakkında doğru bilgi verecek içeriklerin olușturulması önemli hale gelmiștir.

Anahtar Kelimeler: Sitma, Plasmodium, internet, YouTube, sivrisinek kaynaklı hastalıklar, seyahat ilișkili enfeksiyonlar

\section{INTRODUCTION}

Malaria is an important tropical disease that has been seen since the ancient times of human history. It is infecting more than three million people in nearly 100 countries each year and resulting in more than 400000 deaths. Although it is endemic in African countries, it continues to be a global health problem in many parts of the world (1). Since 2015, the World Health Organization (WHO) European Region has been free of malaria. Therefore, malaria has been imported to Europe by travelers and migrants from endemic areas (2-4). Today, there is no indigenous case in Turkey, but imported malaria cases have been seen in workers returning from endemic countries $(5,6)$.

Globally, 219 million malaria cases and 409000 malaria-related deaths have occurred in 2019. Whereas there was a significant decrease in malaria mortality rates from 2015 to 2000, it remained at a similar level in 2020 as in 2015 (1). Death is an unexpected condition for the disease which has effective treatment, defined source, and transmission route. Despite the preventive strategies, about 3 billion people were still at risk of being infected with malaria. Therefore, people need to access correct information about malaria. Studies demonstrated that online platforms and social media are the major sources of medical information $(7,8)$. Unfortunately, none of these platforms are peer-reviewed and they may include a lot of misleading information (9).

YouTube, the most commonly used video-sharing site has more than 2 billion views per day. Every minute a new video is being uploaded and an average user spends at least 15 minutes per day on YouTube (7). During the outbreaks, relevant YouTube videos were watched millions of times (9-11) During the Coronavirus disease 2019 (COVID-19) pandemic, it was suggested to the public to stay at home for reducing transmission. But this situation can cause 
a delay in the treatment-seeking for febrile diseases such as malaria (1). The quality of information on other infectious diseases on YouTube has been evaluated before (12-14). We are not aware of any studies evaluating the role of YouTube as a source of information on malaria. The study aimed to review and evaluate the contents of the most relevant malaria videos on YouTube.

\section{MATERIAL and METHOD}

On April 5 and 6, 2021 the search process was conducted on YouTube by using both English and Turkish keywords as "Malaria", "Plasmodium", and, "Sitma". The first 50 results were recorded in a separate list based on each keyword. There are no videos in Turkish for the keyword of "Plasmodium".
The default YouTube algorithm of relevance was used. The video uniform resource locators (URLs) were saved in a list for further analysis. Of the 150 videos screened, 58 videos in English and 39 videos for Turkish were included in further analysis. Irrelevant videos such as other languages for English videos, videos with no sound or headings, duplicates, and videos longer than 15 minutes were excluded. An analysis of 250 top YouTube channels demonstrates that the optimal length for a YouTube video is between 10 and 16 minutes, therefore the 15-minute was accepted as a threshold value in this study (15) (Figure 1).

The list of videos was analyzed by two independent infectious disease specialists (SK and HB). Approval from the Institutional Review Board was not required as YouTube is a public website and the present study did not include any patient data.
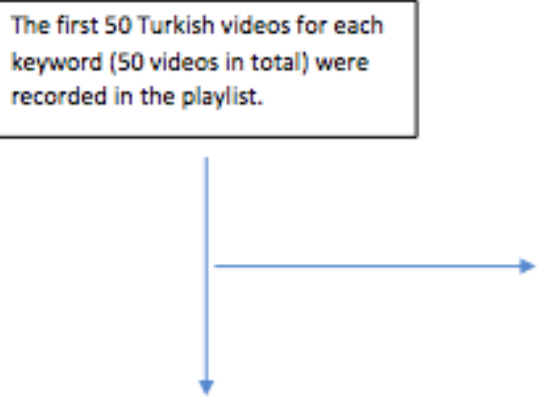

39 Turkish videos were examined.

\section{Turkish videos were excluded}

- Duplications $=7$

- Longer than $15 \mathrm{~min} .=1$

- No accompanying audio/video $=3$
The first $50 \mathrm{English}$ videos for each keyword (100 videos in total) were recorded in the playlist.

\footnotetext{
42 English videos were excluded

- Duplications $=11$

- Longer than $15 \mathrm{~min} .=18$

- No accompanying audio /video $=3$

- Other languages $=10$
}

58 English videos were examined.

Figure 2. Screening process for videos 


\section{Evaluation of the Contents}

The descriptive characteristics, the name of the videos, their upload date, length, view counts, likes, dislikes, comments, and the sources were recorded. The source of videos was categorized into one of four groups: ministry or academic institutions or hospitals, news agencies, health information websites, and others (independent users). Modified DISCERN score for reliability and medical information was conducted. This score has five criteria and each criterion is ranked as 1-0 (yes-no) and scored between zero and five (Supplementary Table 1) (16). A video power index (VPI) was calculated for each video (17).

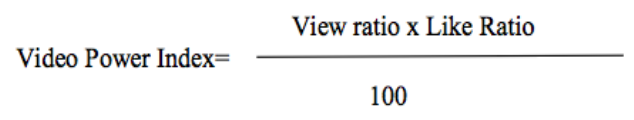
View Ratio $=\frac{\text { Views }}{\text { Days since upload }}$
Like Ratio $=\frac{\text { Likes } \times 100}{\text { Likes }+ \text { Dislikes }}$

Videos were classified as useful if they contained scientific and reliable information about the disease (transmission, signs/symptoms, screening, treatment, and prevention). The videos which include false information were classified as misleading. The videos uploaded from the news channel were coded as news updates.

Videos were grouped based on the number of subscribers of the uploaded channel. This classification is based on YouTube's number of subscribers used for "creator awards". It was grouped as "ordinary" for $\leq 100$ 000, "silver" for 100 000-999 999, "gold" for 1 000 000-9 999 999, and "diamond" for $\geq 10000000$ (18).

\section{Statistical Analysis}

All statistical calculations were made using the "SPSS for Windows version 21" software program (IBM Corporation, IL). Comparisons for categorical variables were executed using the Pearson chisquare test or Fisher's exact test. KolmogorovSmirnov test was performed to check the normality of the continuous variables. Quantitative data were expressed as median (min-max) values in the tables. Categorical data were written as frequency (n) and percentages (\%). Differences between the two groups were compared using the Mann-Whitney $U$ test. Kruskal Wallis test was used for comparisons of more than two groups and the significant $(p<0.05)$ results from the Mann-Whitney test (with Post hoc Bonferroni correction) were performed. Correlation analyses were performed using the Spearman correlation coefficient. Statistical significance was defined as $p<0.05$.

\section{RESULTS}

Ninety-seven videos had a total of 14373885 views, with 281199 likes, 4810 dislikes, and 24339 comments. The days since the videos were uploaded ranged from 115 to 3500 days, whereas the video lengths ranged from 0.16-15.56 minutes. The health information websites $(n=38,39.2 \%)$ were the major source of videos. According to the source, there was a significant difference between Turkish and English videos $(p<0.001)$. Health information websites are dominant sources for English videos (53.4\%) and news agencies are dominant sources for Turkish videos $(48.7 \%)$. The videos (23.7\%) uploaded from the news channels were coded as news updates. The VPI and DISCERN scores of the English videos were significantly higher than Turkish videos (Table 1).

From a total of 97 videos; 66 were classified as useful $(68 \%$, English $(n=54)$, Turkish $(n=12))$ and 8 were classified as misleading (English $(n=2)$, Turkish $(n=6))$. The number of views, likes, views/day, VPI were higher in the useful videos than the misleading videos (Table 2). In 66 useful videos, the number of views, likes, dislikes, comments, views/day, VPI and DISCERN scores of the English videos $(n=54)$ were significantly higher than Turkish videos $(n=12)$. There was no difference in the percentages containing information about the prevalence, transmission, sign/ symptoms, screening, treatment/outcome (Table 3). 
Table 1. Descriptive characteristics of English and Turkish videos

\begin{tabular}{|c|c|c|c|c|}
\hline & English $(n=58)$ & Turkish $(n=39)$ & Total $(n=97)$ & P-value \\
\hline \multicolumn{5}{|l|}{ Source } \\
\hline Ministry/academic/hospital & $7(12.1)$ & $2(5.1)$ & $9(9.3)$ & \\
\hline Health information websites & $31(53.4)$ & 7 (17.9) & $38(39.2)$ & $<0.001$ \\
\hline News agency & $2(3.4)$ & $21(53.8)$ & $23(23.7)$ & \\
\hline Other & $18(31.1)$ & $9(23.1)$ & $27(27.8)$ & \\
\hline Days since release date & $\begin{array}{c}1279 \\
(202-3500)\end{array}$ & $\begin{array}{c}1090 \\
(115-3269) \\
\end{array}$ & $\begin{array}{c}1165 \\
(115-3500)\end{array}$ & 0.086 \\
\hline Video lenght (minutes) & $\begin{array}{c}4.67 \\
(0.40-15.56)\end{array}$ & $\begin{array}{c}2.59 \\
(0.16-14.57)\end{array}$ & $\begin{array}{c}4.05 \\
(0.16-15.56)\end{array}$ & 0.016 \\
\hline VPI & $\begin{array}{c}27.64 \\
(0-1637.73)\end{array}$ & $\begin{array}{c}0 \\
(0-222.3)\end{array}$ & $\begin{array}{c}4.65 \\
(0-1637.73)\end{array}$ & $<0.001$ \\
\hline DISCERN score & $\begin{array}{c}3 \\
(1-5)\end{array}$ & $\begin{array}{c}2 \\
(0-4)\end{array}$ & $\begin{array}{c}3 \\
(1-5)\end{array}$ & $<0.001$ \\
\hline
\end{tabular}

Data are $\mathrm{n}(\%)$ or median (min-max). VPI: Video power index.

Table 2. Content evaluation of videos by descriptive characteristics

\begin{tabular}{|c|c|c|c|}
\hline & Useful $(n=66)$ & Misleading ( $n=8)$ & P-value \\
\hline \multicolumn{4}{|l|}{ Source } \\
\hline Ministry/academic/hospital & $8(12.1)$ & $1(12.5)$ & \\
\hline Health information websites & $37(56.1)$ & $1(12.5)$ & \\
\hline Other & $21(31.8)$ & $6(75.0)$ & \\
\hline Days since release date & $\begin{array}{c}1196 \\
(115-3500) \\
\end{array}$ & $\begin{array}{c}582 \\
(135-2780) \\
\end{array}$ & 0.237 \\
\hline Video lenght (minutes) & $\begin{array}{c}5.29 \\
(0.16-15.56) \\
\end{array}$ & $\begin{array}{c}3.95 \\
(0.49-14.57)\end{array}$ & 0.577 \\
\hline Number of views & $\begin{array}{c}20012 \\
(21-1125784)\end{array}$ & $\begin{array}{c}1823 \\
(165-11109)\end{array}$ & 0.011 \\
\hline Views/day & $\begin{array}{c}18.50 \\
(0-1761)\end{array}$ & $\begin{array}{c}1 \\
(0-19)\end{array}$ & 0.012 \\
\hline Number of likes & $\begin{array}{c}209 \\
(0-14000) \\
\end{array}$ & $\begin{array}{c}19 \\
(2-237) \\
\end{array}$ & 0.024 \\
\hline Number of dislikes & $\begin{array}{c}9 \\
(0-540)\end{array}$ & $\begin{array}{c}3 \\
(0-28)\end{array}$ & 0.112 \\
\hline Number of comments & $\begin{array}{c}11 \\
(0-1298)\end{array}$ & $\begin{array}{c}3 \\
(0-65)\end{array}$ & 0.449 \\
\hline VPI & $\begin{array}{c}17.5 \\
(0-1637.73)\end{array}$ & $\begin{array}{c}0.9 \\
(0-18.24)\end{array}$ & 0.012 \\
\hline DISCERN score & $\begin{array}{c}3 \\
(2-5)\end{array}$ & $\begin{array}{c}1 \\
(0-2)\end{array}$ & $<0.001$ \\
\hline
\end{tabular}

Data are $\mathrm{n}(\%)$ or median (min-max). VPI: Video power index. 
Table 3. Detailed content analysis and descriptive characteristics of useful videos by language

\begin{tabular}{|c|c|c|c|}
\hline & English $(n=54)$ & Turkish $(n=12)$ & P-value \\
\hline \multicolumn{4}{|l|}{ Source } \\
\hline Ministry/academic/hospital & $7(13.0)$ & $1(8.3)$ & \\
\hline Health information websites & $30(59.25)$ & $7(58.3)$ & \\
\hline Other & $17(27.75)$ & $4(33.4)$ & \\
\hline Frequency & $32(59.3)$ & $8(66.7)$ & 0.635 \\
\hline Transmission & $50(92.6)$ & $11(91.71)$ & 1.000 \\
\hline Signs-symptoms & $28(51.9)$ & $8(66.7)$ & 0.351 \\
\hline Screening/testing & $22(40.7)$ & $4(33.3)$ & 0.751 \\
\hline Treatment/outcomes & $29(53.7)$ & $5(41.7)$ & 0.450 \\
\hline Days since release date & $\begin{array}{c}1274.50 \\
(202-3500)\end{array}$ & $\begin{array}{c}1090 \\
(115-3046)\end{array}$ & 0.184 \\
\hline Video lenght (minutes) & $\begin{array}{c}5.29 \\
(0.40-15.56) \\
\end{array}$ & $\begin{array}{c}5.29 \\
(0.16-10.49) \\
\end{array}$ & 0.740 \\
\hline VPI & $\begin{array}{c}32.16 \\
(0-16.37 .73)\end{array}$ & $\begin{array}{c}0.46 \\
(0-14.10)\end{array}$ & $<0.001$ \\
\hline DISCERN score & $\begin{array}{c}3 \\
(2-5)\end{array}$ & $\begin{array}{c}3 \\
(2-3)\end{array}$ & 0.001 \\
\hline
\end{tabular}

Data are $\mathrm{n}(\%)$ or median (min-max). VPI: Video power index.

The DISCERN score of 0 (indicating the least reliable videos) was satisfied by eight $(8.25 \%)$ videos, while the best total score of 5 (indicating the most reliable videos) was satisfied by seven $(7.21 \%)$ videos. In the correlation analysis of all videos; there were positive moderate correlations between the length and the number of views, dislikes, likes, comments, views/day, and VPI. There were positive weak correlations between DISCERN score and the length, the number of views, dislikes, likes, comments, views/day, and VPI (Table 4).

Channels classified by the number of subscribers and features of malaria-related videos were compared. There were only two "diamond" channels in English and no "diamond" channel in Turkish. Due to the low number, two "diamond" channels were not included in the statistical analysis. There was no statistically significant difference between the three groups for days since release day, length, and DISCERN score. Although the percentage of useful videos was higher in "gold" channels, no statistical difference was found between the groups. "Gold" channels had statistically significantly higher numbers of view/ day, view, likes, dislikes, and comments and VPI than "silver" and "ordinary" channels (Table 5).

Twenty-one of the 97 videos (21.6\%) were released after 11 February 2020 when COVID-19 was named (19). The median of days between the release date of these videos and COVID-19 was 114. (min-max; 42334). Fourteen of these videos (66.7\%) were in Turkish and 8 of them contains misleading information about malaria and COVID-19 treatment.

The kappa value for the interobserver agreement was found at 0.825 for Turkish videos and 0.874 for English videos. 
Table 4. Correlation coefficients between the length, DISCERN score, and other parameters of videos

\begin{tabular}{|l|c|c|c|c|}
\hline & \multicolumn{2}{|c|}{ Video Lenght (minutes) } & \multicolumn{2}{c|}{ DISCERN Score } \\
\hline & $\rho$ & P-value & $\rho$ & P-value \\
\hline Days since release date & -0.610 & 0.556 & 0.016 & 0.874 \\
\hline Video length (minutes) & - & - & 0.207 & 0.042 \\
\hline Number of views & 0.443 & $<0.001$ & 0.389 & $<0.001$ \\
\hline Views/day & 0.469 & $<0.001$ & 0.330 & 0.001 \\
\hline Number of likes & 0.504 & $<0.001$ & 0.394 & $<0.001$ \\
\hline Number of dislikes & 0.472 & $<0.001$ & 0.274 & 0.007 \\
\hline Number of comments & 0.455 & $<0.001$ & 0.220 & 0.030 \\
\hline VPI & 0.464 & $<0.001$ & 0.321 & $<0.001$ \\
\hline DISCERN score & 0.207 & 0.042 & - & - \\
\hline
\end{tabular}

VPI: Video power index.

Table 5. Evaluation of videos according to the channels classified by the number of subscribers

\begin{tabular}{|c|c|c|c|c|}
\hline & Ordinary $(n=49)$ & Silver $(n=38)$ & Gold $(n=8)$ & P-value \\
\hline Days since relase day & $968(115-3500)$ & 1472 (219-3479) & $796(202-2846)$ & 0.087 \\
\hline Lenght & $3.23(0.16-15.22)$ & $4.14(0.45-14.16)$ & $5.48(0.5-15.56)$ & 0.748 \\
\hline View & $\begin{array}{c}4700 \\
(21-196800)\end{array}$ & $\begin{array}{c}5800 \\
(57-1028751)\end{array}$ & $\begin{array}{c}162016 \\
(1903-1125784)^{a, b}\end{array}$ & 0.001 \\
\hline View/day & $2(0-81)$ & $5.5(0-548)$ & $255.5(0-1761)^{a, b}$ & 0.003 \\
\hline Likes & $26(0-1500)$ & $67.5(0-14000)$ & $3300(0-12000)^{a, b}$ & 0.005 \\
\hline Dislikes & $3(0-123)$ & $4(0-359)$ & $79(0-540)^{a, b}$ & 0.009 \\
\hline Comments & $2(0-112)$ & $6.5(0-786)$ & $97.5(0-528)^{a, b}$ & 0.010 \\
\hline VPI & $1.8(0-76.95)$ & $4.05(0-515.12)$ & $247.84(0-1637.73)$ a,b & 0.003 \\
\hline DISCERN score & $3(0-5)$ & $3(0-5)$ & $3(1-3)$ & 0.563 \\
\hline Subscriber count & $\begin{array}{c}7240 \\
(0-95200)^{a, c}\end{array}$ & $\begin{array}{c}399000 \\
(102000-759000)^{b, c}\end{array}$ & $\begin{array}{c}2055000 \\
(661000-2610000) \text { a,b }\end{array}$ & $<0.001$ \\
\hline Usefulness & $33(67.3 \%)$ & $25(65.8 \%)$ & 7 (87.5\%) & 0.469 \\
\hline
\end{tabular}

Data are $\mathrm{n}(\%)$ or median (min-max). VPI: Video power index.

a; statistically significant than silver group, b; statistically significant than ordinary group, c; statistically significant than the gold group. 


\section{DISCUSSION and CONCLUSION}

Communicable diseases such as HIV, tuberculosis, and malaria affect billions of people around the world and cause nearly a million deaths every year (20). Health literacy has become a considerable concept across the globe in recent years. In today's world, social media has a big and increasing role in health literacy. The quality of online health information, however, remains questionable (21). More than $80 \%$ of all Americans use internet searches to access health information (22). The percentage of internet searches about health is $55 \%$ in Turkey (23). As a result of a literature search for similar studies, this study seems to be the first comprehensive one that is investigating the content of YouTube videos on malaria. Malaria remains a significant public health problem requiring intense action. It is widespread in tropical and subtropical regions. The disease spreads by an infected female Anopheles mosquito and can be reduced by preventing mosquito bites through the use of nets, insect repellents, or mosquitocontrol measures. Several medications are available for prophylaxis in travelers to the endemic areas. Malaria causes typically nonspecific flu-like symptoms such as fever and myalgia and should be kept in mind especially in those people living in endemic areas or having a travel history to those regions $(4,24)$. These days when all over the world is experiencing the COVID-19 pandemic, it is important to increase the knowledge and awareness of people about malaria to prevent misdiagnosis and delay in treatment.

YouTube presents various unverified information about malaria from different sources that range from international health agencies to personal experiences. The health information websites are dominant sources for English videos and news agencies are dominant sources for Turkish videos in the study. Some of the Turkish videos presented by news agencies are related to the use of chloroquine and hydroxychloroquine during the treatment of COVID-19. This is due to the dominance of searching COVID-19 treatment and leads lack of video sources in the best search list for the people who want to get information about malaria.

Additionally, it was seen that few malaria-related videos were released after COVID-19. Although the WHO has three and the Centers for Disease Control and Prevention (CDC) has one video in the top of 100 English videos, no video is found by Turkish national health organizations including the Ministry of Health in the top 50 Turkish videos. The number of videos presented on social media by the government or academic institutions is not sufficient, which can be explained by the lack of interest of these institutions in social media platforms.

Most of the malaria-related videos were released from "ordinary" $(50.5 \%)$ and "silver" $(39.2 \%)$ channels. "Gold" channels released a small part of the videos (8.2\%), but most of these videos were useful (87.5\%). As expected; the numbers of views, view/day, likes, dislikes, and comments were higher in videos uploaded by "gold" channels. With these results, it can be interpreted that it is necessary to increase the number of health-related content in "gold" channels. Also, health-related content on silver and ordinary channels with high video uploads should be evaluated in terms of information quality.

The percentage of useful videos was $68 \%$ ( $n=66$ of 98 videos). In studies evaluating videos about infectious diseases, approximately $58.8 \%$ and $70.3 \%$ of the videos on YouTube were reported to be useful $(10,25)$. There was a significantly higher viewership of the useful videos $(p=0.011)$. The current content on YouTube in English is more informative. There were only two misleading videos among the included 58 English videos. The most frequently mentioned part of the disease was transmission in useful videos. Prevalence, signs/symptoms, and treatment/outcome were mentioned in nearly half of the videos. But screening/testing was the least mentioned part. The information about the diagnosis of malaria, which can be made with a simple blood smear or rapid card test, should be given to more people through social media platforms.

The modified DISCERN score was used for assessing the reliability of the videos. In total, only seven videos had the best overall score of 5 , while the median DISCERN score of useful videos was 3. English videos had a higher median DISCERN score than Turkish videos. The DISCERN score of all videos was positively 
correlated with length, the number of viewerships, likes, dislikes, and comments. With these results, it can be interpreted that people have more interest in reliable videos.

VPI is an index to measure the power of social media and has been used before $(9,10)$. The median VPI of useful videos was higher than the misleading videos. According to the usefulness, Turkish videos had a lower VPI score.

This study presents some limitations. The first is that YouTube is a highly dynamic platform, where viewership and content change daily. The results may change according to the date of the search. Secondly, the results may change according to the keywords used in the search. Our search was limited to the first 50 videos for each keyword. It was explained previously that YouTube users do not tend to watch videos after a couple of pages (26).

In conclusion, in this study, English and Turkish videos on YouTube about malaria were investigated from the informative and release source perspectives. Each video entered into the list was watched, evaluated, and compared. It was concluded that YouTube videos contain a significant amount of information on malaria. The English videos are more informative than Turkish videos. It can be thought that by increasing the number of videos uploaded by health institutions such as the CDC or WHO, it will be easier for people to access correct information about malaria. The majority of the Turkish videos source was presented by news agencies; those and personal experience videos include misleading unchecked information. International and national health agencies and academic institutions should release more informative videos on malaria and they should increase their interest in those information-sharing platforms considering social media is a constantly growing center to get news and information.

\section{ACKNOWLEDGMENTS}

We would like to thank Ugur Kazancioglu for his help in analyzing English videos. This research did not receive any specific grant from funding agencies in the public, commercial, or not-for-profit sectors.

\section{ETHICS COMITTEE APPROVAL}

* This study does not require Ethics Committee Approval.

\section{CONFLICT OF INTEREST}

The authors declare no conflict of interest.

\section{REFERENCES}

1. World Health Organization 2020. World Malaria Report. Available at https://www.who.int/ publications/i/item/9789240015791.

2. Martini M, Andrea A, Riccardi N, Orsini D. Fifty years after the eradication of Malaria in Italy. The long pathway toward this great goal and the current health risks of imported malaria. Pathog Glob Health 2021;18: 1-9.
3. Kendjo $E$, Thellier $M$, Noël $H$, Jauréguiberry $S$, Septfons A, Mouri O, et al. Mortality from malaria in France, 2005 to 2014. Euro Surveill 2020; 25(36): 1900579.

4. Brindicci G, Santoro CR, Loconsole D, Martinelli D, Prato R, Lonero G, et al. A Cluster of Cryptic Plasmodium falciparum Malaria in African Migrants in Southern Italy, October 2017. Vector-Borne and Zoonotic Dis 2020; 20(12):927-31. 
5. T.C. Ministry of Health 2019. Health Statistics Yearbook. Available at: https://dosyasb.saglik. gov.tr/Eklenti/40566, health-statistics-yearbook2019pdf.pdf.

6. Alver O, Ener B. Bursa'da 2013-2014 yilları arasında sitma epidemiyolojisi. Turk Hij Den Biyol Derg, 2018; 75(1): 37-42.

7. Madathil KC, Rivera-Rodriguez AJ, Greenstein JS, Gramopadhye AK. Healthcare information on YouTube: a systematic review. J Health Inform, 2015; 21: 173-194.

8. Moorhead SA, Hazlett DE, Harrison L, Carroll JK, Irwin A, Hoving C. A new dimension of health care: systematic review of the uses, benefits, and limitations of social media for health communication. J Med Internet Res, 2013; 15(4): e85.

9. Ataç Ö, Özalp YC, Kurnaz R, Güler OM, İnamlık M, Hayran O. YouTube as an information source during the Coronavirus disease (COVID-19) pandemic: Evaluation of the Turkish and English content. Cureus, 2020; 12(10): e10795.

10. Bora K, Das D, Barman B, Borah P. Are internet videos useful sources of information during global public health emergencies? A case study of YouTube videos during the 2015-16 Zika virus pandemic. Pathog Glob Health, 2018; 112: 320-8.

11. Nagpal SJS, A Karimianpour D, Mukhija D, Mohan D, Brateanu A. YouTube videos as a source of medical information during the Ebola hemorrhagic fever epidemic. Springerplus, 2015; 4: 457.

12. Kallur A, Albalbissi A, Carillo-Marin I, Boonpheng B, Kallur L, Kherallah, Y, et al. Doctor YouTube's opinion on seasonal influenza: A critical appraisal of the information available to patients. Digit Health, 2020; 6: 1-6.

13. Ortiz-Martinez Y, Ali-Salloum W, González-Ferreira F, Molinas-Argüello J. HIV videos on YouTube: helpful or harmful. Sex Transm Infect, 2017; 93(7): 481.

14. Ortiz-Martínez $\mathrm{Y}$, Castellanos-Mateus S, RojasMoreno H, Suárez-Molina J. YouTube videos as a source of Hepatitis C-related information: A crosssectional study. Travel Med Infect Dis, 2020; 37: 101708.

15. Twinword.com, 6 common features of top 250 YouTube channels. Available at: https://www. twinword.com/blog/features-of-top-250-YouTubechannels/.
16. Charnock D, Shepperd S, Needham G, Gann R. DISCERN: an instrument for judging the quality of written consumer health information on treatment choices. J Epidemiol Community Health, 1999; 53: 105-11.

17. Erdem MN, Karaca S. Evaluating the accuracy and quality of the information in kyphosis videos shared on YouTube. Spine 2018; 43: 1334-39.

18. YouTube creator awards. Available at: https:// www. YouTube.com/creators/how-things-work/ programs-initiatives/awards/.

19. World Health Organization. Listings of WHO's response to COVID-19. Available at. https://www. who.int/news/item/29-06-2020-covidtimeline.

20. World Health Organization 2015. Accelerating Progress on HIV, tuberculosis, malaria, hepatitis, and neglected tropical diseases. Available at: https:// www. who.int/about/structure/organigram/htm/ progress-hiv-tb-malaria-ntd/en/.

21. World Health Organization 2013. Health literacy the solid facts. Available at: https://apps.who.int/ iris/bitstream/handle/10665/128703/e96854.pdf.

22. Chen YY, Li CM, Liang J, Tsai CC. Health information obtained from the internet and changes in medical decision making: questionnaire development and cross-sectional survey. J Med Internet Res, 2018; 20(2): e47.

23. Statista 2018. Sources of healthcare information for individuals in Turkey as of 2018. Available at: https: / / www.statista.com/statistics/890853/ sources-of-healthcare-information-turkey/.

24. Pannu AK. Malaria today: advances in management and control. Trop Doc, 2019; 49: 160-4.

25. Khatri P, Singh SR, Belani NK, Yeong YL, Lohan R, Lim WL, et al. YouTube as source of information on 2019 novel coronavirus outbreak: a cross sectional study of English and Mandarin content. Travel Med Infect Dis, 2020; 35: 101636.

26. MacLeod MG, Hoppe DJ, Simunovic N, Bhandari M, Philippon MJ, Ayeni OR. YouTube as an information source for femoroacetabular impingement: a systematic review of video content. Arthroscopy, 2015; 31: 136-42. 